BLS 32, No 1 2006. DOI: http://dx.doi.org/10.3765/bls.v32i1.3464 (published by the Berkeley Linguistics Society and the Linguistic Society of America)

\title{
A Case of Rare Fluid Intransitivity in Europe: Russian
}

\section{JOHANNA NICHOLS}

University of California, Berkeley

\section{Introduction}

The subject alignment type best known as stative/active subsumes two different patterns: split-S, where intransitive verbs lexically require A or O coding on their subjects; and fluid-S, where most or all verbs can take either kind of coding depending on semantic factors such as volitionality, control, etc. ${ }^{1}$ Examples of classic split-S and fluid-S systems are in (1)-(3) and (4)-(5) respectively. ${ }^{2}$

(1) Lakhota (Siouan; Mithun 1991:514-5, hyphens added). $\Sigma=$ first element of bipartite stem.

a-wá-'u

$\Sigma$ 1SG.[A]-bring

'I brought it'

(2) wa-psíča

1SG.[Sa]-jump

'I jumped'

(3) wa-lową 1SG.[Sa]-sing

'I'm singing' a-má-'u $\Sigma$ 1SG.[O]-bring

'he brought me'

ma-Xwá

1SG.[So]-sleepy

'I'm sleepy'

ma-hịxpaye

$1 \mathrm{SG}$.[So]-fall

'I fell'

(4) Batsbi/Tsova-Tush (East Caucasian; Georgia)

so vozhen-sŏ

I.ABS[So] fell-1sg.ABS

'I fell (accidentally)'

$1 \mathrm{~S}, \mathrm{~A}$, and $\mathrm{O}$ as in Dixon 1979. $\mathrm{Sa}=\mathrm{S}$ coded like A; $\mathrm{So}=\mathrm{S}$ coded like $\mathrm{O}$.

${ }^{2}$ Clause roles (A, S, O; Sa, So, etc.) are identified in interlinears in square brackets. 


\section{Johanna Nichols}

(5)

$$
\begin{aligned}
& \text { as vuizhn-as } \\
& \text { I.ERG[Sa] fell-1s.ERG } \\
& \text { 'I fell (on purpose)' }
\end{aligned}
$$

The split-S type is infrequent, making up only $14 \%$ of the sample languages in Nichols 1992. The fluid-S type is very rare: Dixon 1994:78ff. lists only Batsbi, Acehnese, spoken Tibetan, and Baniwa as belonging to this type. A few more languages have a split implemented with fluidity for one of the two classes of verbs (Koasati and other Muskogean languages have fixed So vs. fluid Sa/So: Kimball 1991:249, 251; Axininca Campa has fixed Sa vs. fluid So/Sa: Payne 1981:14). The majority of split-S and fluid-S languages are from the Americas, followed by the Pacific; they are quite rare in Eurasia and more so in Africa.

This paper argues that Russian is a fluid-S language of the same type as most of the American and Pacific ones. Though the morphology that implements the fluid-S type is available to all Slavic and Baltic languages, fluidity appears to be found only in one Slavic branch. Since the correlations of the Russian phenomenon with tense/aspect, Aktionsart, subject and object animacy, volitionality/control, and viewpoint are relatively well understood, they can be used to raise hypotheses for testing on other stative-active languages.

Only if object alignment is brought into the picture can Russian be described as a fluid-S language. This requires, in addition to Dixon's (1979) S, A, and O, abbreviations for the two object arguments of ditransitives. I will use $\mathrm{P}$ for the more patient-like or theme-like object and $\mathrm{G}$ for the more goal-like object. Thus the argument configurations for the basic valence types are:

$\begin{array}{ll}\text { Intransitive } & \text { S } \\ \text { Monotransitive } & \text { A O } \\ \text { Ditransitive } & \text { A P G }\end{array}$

The morphological coding of $\mathrm{S}$ in ergative languages, and the "stative" pattern in split-S and fluid-S languages, can be described loosely as So or more precisely as either $\mathrm{Sp}$ or $\mathrm{Sg}$, depending on whether the language has the direct/indirect object type or the primary/secondary object alignment type (in the terms of Dryer 1986). In direct/indirect object languages, $\mathrm{P}=\mathrm{O}$; in primary/secondary object languages, $\mathrm{G}=\mathrm{O}$. (6)-(7) illustrate $\mathrm{P}=\mathrm{O}$ alignment in Russian (a direct object language), and (8)-(9) illustrate $\mathrm{G}=\mathrm{O}$ alignment in Tzotzil (a primary object language).

\begin{tabular}{|c|c|}
\hline dala & detjam \\
\hline I.NOM[A] gave & children-DAT $[\mathrm{G}]$ book-ACC $[\mathrm{P}]$ \\
\hline
\end{tabular}

$$
\begin{aligned}
& \text { ja chitaju knigu } \\
& \text { I.NOM[A] read-1SG book-ACC[O] } \\
& \text { 'I'm reading a book' }
\end{aligned}
$$


(8) Tzotzil (Mayan, Guatemala; Dryer 1986:818 citing Aissen 1983:277, 280) mi $\check{c}$ - a - mah - on Q ASP-2SG.ERG[A]-hit-1SG.ABS[O]

'Are you going to hit me?'

$$
\begin{aligned}
& \text { mi mu } \breve{s} \text { - } \mathrm{a} \text { - čon - b - on l-a-čitome } \\
& \text { Q NEG ASP-2SG.ERG[A]-sell-BEN[G]-1SG.ABS[P] the-your-pig } \\
& \text { 'Won't you sell me your pigs?' }
\end{aligned}
$$

In (4) above, So is more precisely Sp, as Batsbi is a direct object language. But in (3), the right-hand examples illustrating So alignment are more precisely $\mathrm{Sg}$, as Lakhota is a primary object language. Lakhota is typical: most split-S and fluid-S languages have $\mathrm{G}=\mathrm{O}$ alignment (Nichols $200 \square$ ), and this means that $\mathrm{Sa} / \mathrm{So}$ in its typical form is more precisely $\mathrm{Sa} / \mathrm{Sg}$. It should also be emphasized that in many split-S languages a few two-argument verbs are usually included among the "statives". Usually these are verbs of emotion and/or perception (such as 'like', 'fear', 'see'). The subject of a two-argument verb is A, so for most languages the "stative" verb class should be described as consisting of $\mathrm{Sg}$ and $\mathrm{Ag}$ verbs. Thus the split-S type can be described more precisely and more accurately as having the alignment $\mathrm{Sa} / \mathrm{Sg}$ and sometimes also $\mathrm{Aa} / \mathrm{Ag}$.

So described, the split-S type is not at all rare in Eurasia. The dative-subject construction that is widespread in southern Eurasia (Masica 1976, 1991) and central Europe (Bossong 1998) is precisely $\mathrm{Sa} / \mathrm{Sg}$ and $\mathrm{Aa} / \mathrm{Ag}$ (Nichols 200ロ). (10)-(13) illustrate So, A, Sg, and Ag from Ingush (Nakh-Daghestanian: Caucasus).

(10) so wa-vyzhaav

1S.ABS[So] down-fell

'I fell down'

(11) aaz kinashjka diishar

1S.ERG[A] book[O] read

'I read a book'

$$
\begin{array}{ll}
\text { suona shiila jy } \\
\text { 1S.DAT }[\mathrm{Sg}] & \text { cold be.PRES }
\end{array}
$$

'I'm cold'

(13) suona hwazaljg bwarjg-deira 1S.DAT[Ag] bird[O] eye-saw

'I saw a bird' 


\section{Johanna Nichols}

\section{Russian dative reflexives and dative intransitives}

Russian has a number of verbs that take dative subjects and are reflexive in form. Most are impersonal, i.e. the verb does not agree with anything (because there is no nominative subject for it to agree with) and appears in the default third person singular or neuter form. A few have a nominative object with which the verb agrees $((14 b)$ below). Most have non-reflexive counterparts that take nominative subjects. (In (14) the reflexive and non-reflexive verbs are not cognate.)

(14) a. Ja ljublju klassicheskuju muzyku.

I.NOM[A] like-1SG classical-ACC music-ACC[O]

I like classical music.

b. Mne nravitsja èta muzyka.

me.DAT[Ag] like-REFL this-NOM music-NOM[Oa]

I like this music.

(15) a. Ja xochu kupit' mashinu.

I.NOM[A] want buy-INF car-ACC

'I want to buy a car'

b. Mne xochetsja poprobovat' shokolad.

me-DAT[Ag] want-REFL try-INF chocolate-ACC

'I'd like to try (the/some) chocolate'

(16) a. Ja dumaju, chto ...

I.NOM[A] think-1SG that ...

'I think that ...'

b. Mne dumaetsja, chto ... me-[Ag] think-3SG-REFL that ...

'I'm inclined to think that...'

(17) a. Ja slyshu ego golos

I.[A] hear-1SG his voice.ACC[O]

'I hear his voice'

b. Mne slyshitsja ego golos

me.DAT[Ag] hear-3SG-REFL his voice.NOM[Oa]

'I can hear his voice'

Several of these have cognates in the other Slavic languages and reconstruct to Proto-Slavic (this is true of the verbs of (14b) and (15b)). What makes Russian distinctive is the existence of large numbers of pairs like the following: 
(18) a. On xorosho rabotaet he.NOM[S] well work-3SG

He works well. He's working well.

b. Emu (zdes') xorosho rabotaetsja

him.DAT[Sg] (here) well work-3SG-REFL

He can work well here. He is able to get down to work here.

(19) a. On chitaet

he. [S] reads

He reads. He's reading.

b. Emu (xorosho) chitaetsja

him.DAT[Sg] (well) read-REFL

He's able to get down to reading.

Dative-reflexive constructions in general, i.e. all those like the (b) examples in (14)-(19), share a number of properties that distinguish them from nominativesubject constructions. One is that verbs with nominative subjects, if imperfective, can easily be interpreted as durative and translated with English progressives (as in the translations above), while the dative-reflexive ones cannot; they can be generic, intermittent, potential, etc. but not durative. A second is that some verbs with nominative subjects can describe activities, while those with datives describe propensities, potential to concentrate, inclinations, perceptions, and the like. Third, for verbs of cognition, perception, etc., those with nominative subjects describe opinions, attitudes, stances, and more or less durable or unhindered perceptions, while those with datives describe reactions, intermittent or contingent perceptions, and the like. Fourth, the perspective in the (b) examples is that of the noun or pronoun in the dative: the speaker reports that person's viewpoint and experience (Nichols 1986; this is discussed in section 4 below).

Examples like (18)-(19) are the main concern of this paper. They share all these properties and have additional distinctive ones. First, as shown in these examples, they tend to occur with negation, adverbials of place or time, and other qualifiers that explicitly indicate contingency of the situation or event. Second, while (14)-(17) have objects or clausal complements, examples like (18)-(19) do not and cannot (Franks 1995:365-6). Some of these are intransitive in their nonreflexive form, like rabotat' 'work' of (18). Others are transitive, like chitat' 'read' of (19), but cannot take an object in this construction:

* Emu segodnja ne chitaetsja gazet/gazety/gazetu/gazeta him-DAT[Ag] today NEG read-REFL newspaper-GEN.PL/NOM= ACC.PL $=$ GEN.SG/ACC.SG/NOM.SG[O]

'He just doesn't feel like reading the paper(s) today', 'He just can't get down to reading the paper today' 


\section{Johanna Nichols}

(The object 'newspaper(s)' in (20) is put in all case forms that might be used for a direct object or subject of passive, to show that the problem is not the case of the object but its very presence.) Because no object is possible with this kind of dative-reflexive construction, I interlinearize the subject as S in (19) and will call this the dative-S construction. The broader category comprising all examples like (14)-(19) is the dative-subject construction, and (14)-(17) more specifically illustrate the dative- $A$ construction. ${ }^{3}$

Third, the dative-S construction has a distinctive semantics: it implies that there is something the subject is supposed to do or considers it appropriate to do but is disinclined to do or cannot get himself/herself to do, hence the glosses 'just doesn't feel like', 'can't get down to', etc. This is different from ordinary volitionality/non-volitionality and might be described as thwarted or ambivalent volitionality (Timberlake 2004:436-7 calls these reflexives modal for that reason; Franks 1995:364 and several earlier sources call them dispositional; for semantics and much bibliography see Gerritsen 1991:173-200).

Fourth, the dative-S constructions are paired with nominative-S constructions whose verbs do not form perfectives. Rabotat' 'work' of (18) is a durative verb which, like other verbs of this Aktionsart, has no perfective. There are related prefixally derived verbs which do have perfectives, such as porabotat' 'work briefly, work a bit, work for awhile' and zarabotat' 'start up (of engine, etc.)', but these are different verbs rather than perfectives of rabotat'. In contrast, the dative$\mathrm{S}$ verbs, which as noted above are not durative, do have perfectives. Most often they form inceptives with $z a$-, and occasionally a telic perfective with po-:

Emu zarabotalos'

him-DAT $z a$-work-REFL

'(After not being able to get down to work) he got his concentration back', 'he got inclined to work', 'he began working with (renewed) energy'

(22) Xorosho porabotalos'! Tri dnja posvjatil dorabotke plana schetov ... well po-WORK-REFL

'(Oh boy) did I ever get a lot done! I was able to devote three whole days to working out the account plan (text continues: Nobody bothered me, everybody but the accounting department was on vacation. It was great!)' (forum.klerk.ru/showjournal.php?journalid=411)

These appear to be true perfectives of the unprefixed dative-reflexive verbs, and they differ from the prefixed derivatives of nominative-subject verbs. The $z a-$ prefixed inceptives are not as strongly inceptive as the $z a$-prefixed inchoatives of

3 This terminology assumes that all these datives are syntactically subjects. To be sure, they behave differently from nominative subjects (see Moore \& Perlmutter 2000), but I assume that this is because of their non-nominative case and not because of their syntax. 


\section{Fluid intransitivity in Russian}

nominative-subject verbs (such as zaplakat' 'burst into tears, start to cry'; for the properties of these see Stoll 2001:49-51) but are ordinary perfectives of verbs whose imperfective Aktionsart is (as described above) inceptive or intermittent:

Xot' i pjatnica, a vse ravno zarabotalos' $s$ utra s èntuziazmom ... though Friday, nonetheless $\boldsymbol{z a}$-work-REFL in morning with enthusiasm 'Though it was Friday, still we began work enthusiastically' (http://www.e-xecutive.ru/oneday/article_1736/forum_42300/msg_38231/:)

And the verb of (22) is not an attenuative durative like porabotat' 'work a bit, work awhile' but appears to be a telic 'work (and accomplish something)'.

Fifth, the dative-S construction is highly productive and can be formed from nearly every non-reflexive verb with an agentive subject. Moore \& Perlmutter 2000:384-5 describe them as being formed only from unergative verbs and not from unaccusatives:

* Vase ne rastetsja
Vasja-DAT NEG grow-REFL
'Vasja doesn't feel like growing, just can't seem to grow'

Contrast this stance verb (unergative):

Ej javno ne stojalos' na meste. Ona otbegala v storonu ... her-DAT clearly NEG stood-REFL in place She-NOM ran away It [game animal] obviously couldn't stand still and ran away. (ps.1september.ru/articlef.php?ID=200408007)

However, not all unergatives can take dative subjects. Aktionsart seems to play an important role: the determinate verb idti 'go (in one direction, to one goal)' cannot take a dative subject while its indeterminate xodit' 'go (around, in more than one direction, to more than one place)' can:

(26) a. *mne ne idetsja me-DAT NEG go-REFL ('I don't feel like going')

b. (segodnja) mne ne xoditsja today me-DAT NEG go.INDET-REFL 'I just don't feel like walking around (today)'

Finally, the dative-S construction can be formed only from a verb that is lexically intransitive or, if transitive, able to occur without an object. Whereas English can use virtually any transitive or oblique-object verb with a null generic or unspecified object (I'm eating. I'm just looking. I can't come to the phone now, 


\section{Johanna Nichols}

I'm painting. Don't bother me while I'm sewing. It's midnight and I'm still ironing. We're buying today but expect to be selling tomorrow), in Russian this possibility is much more limited and is lexically restricted. For instance, the two partial synonyms est' and kushat' 'eat' differ in that only kushat' can easily be used without an object; and of these two only kushat' takes the dative-subject form in productive contexts with any frequency. ${ }^{4}$ Since objectless use is lexically restricted, verbs like that in (19b) can be regarded as derived lexically from intransitive verbs rather than syntactically from objectless clauses.

Thus, in summary, the dative-S construction can be used with any verb that is intransitive, not already reflexive, agentive or at least with a responsible subject, and non-durative. Its most salient semantic properties are its modal sense (inclination or ability - or, more commonly, disinclination or inability - to do something that it would be natural or expected or appropriate to do), which is unique to the dative-S construction, and intermittent, contingent, or transient Aktionsart (common to most dative-subject constructions), which enables them to perfectivize when their non-reflexive source verbs cannot. If dative-subject constructions like those in (14)-(17) had greater text or lexical frequency than they do, Russian could be called a split-subject language, but in fact they are just a minor type of subject coding in Russian. The dative-S construction, however, is lexically unlimited in that it is available to any intransitive with the right Aktionsart and semantics, and this allows Russian to be considered a fluid-S language of the typical sort, i.e. with $\mathrm{Sa} \sim \mathrm{Sg}$ subject coding. (Implicit in this discussion is the assumption that the impersonal and reflexive morphology on the verb in Russian dative-subject constructions is the consequence, not the cause, of the nonnominative subject case. Russian, like other Indo-European languages with case, rigidly limits verbal agreement to nominative subjects, and the impersonal form and perhaps the reflexivization are responses to non-nominative subjects.)

It should be noted that dative-subject constructions are very different from passives in Russian. In a passive, the patient is an $\mathrm{S}$ and the agent a nonargument; the agent is in the instrumental case, not the dative; the verb agrees with the $\mathrm{S}$ (which is nominative); and the verb is reflexive only in imperfectives, while perfective passives use the past passive participle plus 'be'. In the dativesubject construction, there is a case change but no diathesis: the dative-marked noun or pronoun is still A or $\mathrm{S}$. The verb is reflexive in either aspect.

\section{Other Slavic languages}

All Slavic languages have dative-subject constructions, and both the construction

\footnotetext{
4 Estimates based on Google searches for mne kushaetsja and mne estsja (me-DAT eat-REFL) 'I feel like eating' and emu kushaetsja, emu estsja (him-DAT eat-REFL) 'he feels like eating'. Estsja actually has higher raw frequency but most examples are folkloristic or in formulaic expressions (e.g. ne spitsja, ne estsja 'can't sleep or eat'), but kushaetsja is used in all kinds of contexts. Both verbs are infrequent in this construction (frequencies in the Russian National Corpus are 0 or 1), probably because there are more idiomatic ways of saying 'have an appetite' and the like in Russian.
} 
and some of the verbs that take it reconstruct to Proto-Slavic. The fluid dative-S construction as described above appears to be limited to East Slavic (Russian, Belarusian, Ukrainian; see Shevelov 1963:128 for dative-S constructions in Ukrainian). The other Slavic languages have a dative-subject construction that is as productive and widely used as the Russian dative-S construction, and has similar semantics (glossed 'feel like', 'inclined', etc.), but differs in that it is not limited to intransitives and an object can be present. In Polish and Slovenian the object is accusative and the verb is impersonal; in the other languages the patient is nominative and the verb agrees with it:

(27) Polish

Jankowi czytało się tę książkę z przyjemnością

J.-DAT read REFL that-ACC book-ACC with pleasure 'Janek read this book with pleasure' (Rivero 2002:472)

(28) Slovenian

Janezu se je jedlo jagode J-DAT REFL AUX. eat-NEUT strawberries-ACC 'Janez felt like eating strawberries' (Rivero 2002:472)

(29) Czech

Ta kniha se Janovi četla dobře that-NOM book-NOM REFL J-DAT read-FEM well 'Jan read that book with ease'

(Rivero 2002:473)

(30) Bosnian/Croatian/Serbian

Pije mi se kava drink me-DAT REFL coffee-NOM

'I'd like to have some coffee'
Bulgarian $^{5}$
$\mathrm{Na}$ Ivan mu
se četjaxa knigi
DAT Ivan 3S.DAT REFL read-PL books
'Ivan felt like reading books'
(Rivero 2002:473)

In Polish this construction is much like the impersonal passive except for using the dative case rather than the instrumental. In the languages with nominatives, it is much like an ordinary passive again except for the dative. In the most detailed discussion to date, Marušić and Zaucer (प०००) show that the Slovenian construction is not monoclausal like the Russian one but is biclausal with a null modal predicate. In (32), the adverb včeraj 'yesterday' applies to the null modal while jutri 'tomorrow' applies to 'go'.

(32) Slovenian Včeraj se mi ni šlo jutri domov yesterday REFL me.DAT NEG go-PAST-NEUT tomorrow home

'Yesterday I didn't feel like going home tomorrow'

\footnotetext{
5 The proclitic $m u$ agrees with $N a$ Ivan.
} 


\section{Johanna Nichols}

This is impossible in Russian. (In addition, the verb is that of Russian (26a), which is made ungrammatical precisely by this verb in Russian.) These differences suggest that Slovenian has fewer, probably many fewer, dative-subject verbs than Russian, as most dative subjects prove to be governed by this dativetaking null modal predicate. Slovenian is not fluid-S at all, and this probably applies to at least some of the other Slavic languages as well.

\section{Two cross-linguistic hypotheses}

As noted above, the case of Russian subjects affects the discourse-pragmatic perspective: the nominative-subject construction has external viewpoint (the reader or hearer sees, as it were, the referent of the nominative noun or pronoun), while the dative-subject construction has internal viewpoint (the reader or hearer shares the perspective of the referent of the dative). This was established by close analysis of a few texts, and chiefly for dative-A verbs (Nichols 1986). Is it true of dative-S constructions as well? (33) on the next page gives evidence from the Russian National Corpus (www.ruscorpora.ru) suggesting that it is. Frequencies are shown for first and third person singular subjects, both nominative and dative, for a few verbs that easily take a dative $\mathrm{S}$. The proportion of first person $\mathrm{S}$ is much higher for dative than for nominative. I hypothesize, then, that what may be called dative viewpoint is a regular cross-linguistic concomitant of $\mathrm{Sg}$ and $\mathrm{Ag}$ constructions. A ready counterexample is Icelandic, where dative-subject constructions have speaker viewpoint (Barðdal 2004:124-131). Wider testing is needed, among non-European languages with dative subjects and among stativeactive languages.

A second hypothesis concerns the typical tense/aspect/Aktionsart properties of different alignment types. As seems to have been first pointed out by Regamey (1954), ergativity is prototypically centered on a change undergone by a patient

and is therefore associated with past and perfective categories, while accusativity is centered on the action of an agent and is associated with present and imperfective categories. The Russian facts reviewed here suggest that dative subject coding has a prototypical configuration different from either of these two: it is associated with experiencers and with the onset of perception or cognition. The three prototypical configurations are shown in (34).

(33) Frequencies of selected verbs with singular pronoun subject: nominative $j a$ 'I', on/ona 'he/she' vs. dative mne 'I-DAT', emu/ej 'he/she-DAT'. Figures for nominatives are estimates. $\left(\mathrm{p}<0.000 \ldots, \mathrm{X}^{2}=58.046\right)$

\begin{tabular}{|c|c|c|c|c|}
\hline$\underline{\text { Person }}$ & & Nominative & & Dative \\
\hline $1^{\text {st }}$ & work & ja rabotaju & 1000 & mne rabotaetsja \\
\hline $3^{\mathrm{rd}}$ & & on/ona rabotaet & 1500 & emu/ej rabotaetsja \\
\hline $1^{\text {st }}$ & read & ja chitaju & 900 & mne chitaetsja \\
\hline $3^{\text {rd }}$ & & on/ona chitaet & 670 & emu/ej chitaetsja \\
\hline
\end{tabular}


Fluid intransitivity in Russian

$\begin{array}{lllrlc}1^{\text {st }} & \text { write } & \text { ja pishu } & 900 & \text { mne pishetsja } & 9 \\ 3^{\text {rd }} & & \text { on/ona pishet } & 2200 & \text { emu/ej pishetsja } & 8 \\ 1^{\text {st }} & \text { sleep } & \text { ja splju } & 600 & \text { mne spitsja } & 39 \\ 3^{\text {rd }} & & \text { on/ona spit } & 1100 & \text { emu/ej spitsja } & 19 \\ \text { TOTAL } 1^{\text {st }} & & 2400 & & 65 \\ & & & 5500 & & 33\end{array}$

\begin{tabular}{|c|c|c|c|}
\hline & $\underline{\mathrm{S}}=\mathrm{O}$, Ergative & $\underline{S}=\mathrm{A}$, Accusative & $\underline{\mathrm{S}}=\mathrm{G}$, "Dative" \\
\hline Aspect: & $\begin{array}{l}\text { Punctual, } \\
\text { perfective }\end{array}$ & $\begin{array}{l}\text { Durative, } \\
\text { progressive }\end{array}$ & $\begin{array}{l}\text { Intermittent, } \\
\text { inceptive }\end{array}$ \\
\hline Tense: & Past & Present & Generic \\
\hline Predicate: & Change of state & Activity, attitude & Reaction \\
\hline Role: & Patients & Agents & Experiencers \\
\hline
\end{tabular}

Russian and its sisters, a loner fluid $\mathrm{Sa} / \mathrm{Sg}$ language family in Eurasia, can probably be presumed to have followed universals or prototypes in innovating this rare alignment type, so they can help us spot those universals. The copious lexical and textual resources for these languages, and their neat grammaticalization of aspect, make it possible to use their dative-subject constructions as a basis for cross-linguistic hypotheses, and I invite other linguists to falsify the claim that $\mathrm{Sg}$ and Ag coding are preferentially associated with dative perspective, inceptive aspect, generic tense, experiencers, and transient reactions.

\section{References}

Aissen, Judith. 1983. Indirect object advancement in Tzotzil. David Perlmutter, ed., Studies in Relational Grammar 1. Chicago: University of Chicago Press.

Barðdal, Jóhanna. 2004. The semantics of the impersonal construction in Icelandic, German, and Faroese: Beyond thematic roles. Studies in Germanic Typology, ed. Werner Abraham, 101-130. Berlin: Akademie Verlag.

Bossong, Georg. 1998. Le marquage de l'expérient dans les langues d'Europe. In Actance et valence dans les langues de l'Europe, ed. Jack Feuillet, 259-294. Berlin: Mouton de Gruyter.

Dixon, R. M. W. 1994. Ergativity. Cambridge: Cambridge University Press.

Dixon, R. M. W. 1979. Ergativity. Language 55.59-138.

Dryer, Matthew. 1986. Primary objects, secondary objects, and antidative. Language 62:808-845.

Franks, Steven. 1995. Parameters of Slavic Morphosyntax. New York-Oxford: Oxford University Press.

Gerritsen, Nelleke. 1990. Russian Reflexive Verbs: In Search of Unity in Diver- 
sity. Amsterdam-Atlanta: Rodopi.

Holisky, Dee Ann. 1987. The case of the intransitive subject in Tsova-Tush (Batsbi). Lingua 71.103-132.

Kimball, Geoffrey. 1991. Koasati Grammar. Lincoln, Nebraska: University of Nebraska Press.

Marušić, Franc, and Rok Zaucer. 800.. On the intensional FEEL-LIKE construction in Slovenian: A case for a phonologically null verb. Natural Language and Linguistics Theory 24. 1093-1159.

Mithun, Marianne. 1991. Active/agentive case marking and its motivations. Language 67:510-546.

Moore, John, and Perlmutter, David M. 2000. What does it take to be a dative subject? NLLT 18:373-416.

Nichols, Johanna. 2008. Why are stative-active languages rare in Eurasia? Typological perspective on split subject marking. In Mark Donohue and Søren Wichmann, eds., The Typology of Semantic Alignment Systems, 121139. Oxford: Oxford University Press.

Nichols, Johanna. 1992. Linguistic Diversity in Space and Time. Chicago: University of Chicago Press.

Nichols, Johanna. 1986. Aspect and inversion in Russian. In The Scope of Slavic Aspect, ed. M. S. Flier and A. Timberlake, 94-117. Columbus: Slavica.

Payne, David L. 1981. The phonology and morphology of Axininca Campa. SIL Publication 66. Arlington, TX: SIL and University of Texas-Arlington.

Regamey, C. 1954. A propos de la "construction ergative" en indo-aryen moderne. In Sprachgeschichte und Wortbedeutung: Festschrift Albert Debrunner, 363-384. Bern: Francke.

Rivero, María Luisa. 2002. Reflexive clitic constructions with datives: Syntax and semantics. In Annual Workshop on formal Approaches to Slavic Languages: The Amherst Meeting., eds. Wayles Browne, J-Y. Kim, B. H. Partee and R. A. Rothstein, 469-494. Ann Arbor: Michigan Slavic Publications.

Shevelov, George Y. 1963. The Syntax of Modern Literary Ukrainian. (Slavistic Printings and Reprintings, 38.) The Hague: Mouton.

Stoll, Sabine. 2001. The Acquisition of Russian Aspect. Ph.D. dissertation, University of California, Berkeley.

Timberlake, Alan. 2004. A Reference Grammar of Russian. Cambridge: Cambridge University Press. 